\title{
Sound clue in hunt for MH370
}

\author{
Hydroacoustic signal caught by sensors in the Indian Ocean may be linked to crash \\ of Malaysian airliner.
}

\section{BY DECLAN BUTLER}

$\mathrm{R}$ esearchers are exploring what may be the first promising lead in months in the search for the wreckage of Malaysian Airlines flight MH370. Sensitive microphones on the ocean floor off Australia picked up a distinctive signal at about the time that the Boeing 777 aeroplane is believed to have crashed in the Indian Ocean. The findings, announced by Australian scientists last week, offer a rough location for the source of the sound and are being followed up by search authorities.

The signal was discovered by a team led by Alec Duncan, an underwater acoustics specialist at Curtin University's Centre for Marine Science and Technology in Perth, Australia. It was recorded at 01:30 coordinated universal time (UTC) on $8 \mathrm{March}$; the last transmission from flight MH370, an electronic 'handshake' between the aircraft's communication system and a satellite, took place at 00:19 UTC, when the plane is estimated to have run out of fuel.

The sound is believed to have originated somewhere along a strip running to the northwest of the Indian Ocean (see 'Sound trackers'). That is out of the range of the current search, which was determined by analysis of the satellite communication data and is being led by the Australian Transport Safety Bureau (ATSB). However, the techniques used are well-established. "The ATSB will continue to discuss the analysis of this information with Curtin University for the purposes of informing the search," says a spokesperson for the Joint Agency Coordination Centre (JACC) in Canberra, which is coordinating the Australian government's support for the search.

The Curtin team emphasize that the sound may have come from other sources, such a small earthquake, but thinks that the lead is worth pursuing. It is now preparing to retrieve more hydroacoustic data from the ocean off northwestern Australia.

Duncan's team found the signal while analysing data from an acoustic station in Perth Canyon about 40 kilometres west of Rottnest Island near Perth. It is one of six stations operated by Australia's Integrated Marine Observing System (IMOS), which was set up to make physical, chemical and biological observations of the ocean basin. Duncan then confirmed the signal using data from an acoustic station off Cape

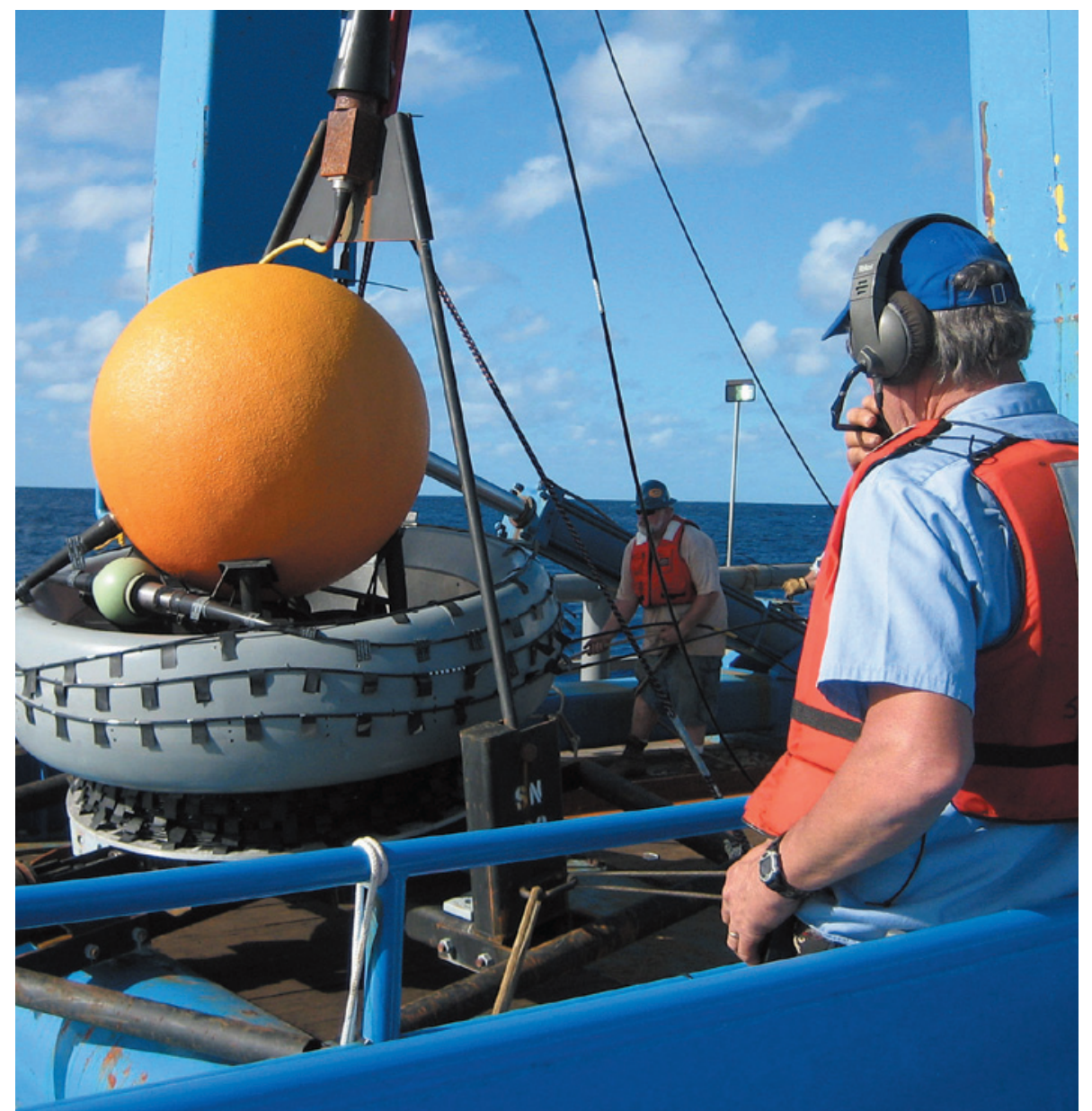

Hydrophones run by the Comprehensive Nuclear-Test-Ban Treaty Organization track explosions in the sea.

Leeuwin on the southwest tip of Australia that were provided by the Comprehensive NuclearTest-Ban Treaty Organization (CTBTO).

The CTBTO, a nuclear-test monitoring body based in Vienna, maintains a global network of seismic and radioisotope detectors, as well as other instruments. The network includes six hydrophone stations that monitor for explosions in the ocean, but can also pick up other sounds such as whale calls at great distances. Cape Leeuwin is one of two CTBTO acoustic stations in the Indian Ocean. Duncan also analysed data from the other, off Diego Garcia island in the middle of the Indian Ocean, but found nothing. The data were too polluted by noises from seismic surveys, he says.

The IMOS stations have just one microphone each, so alone cannot provide detailed information on the direction of sounds. But the CTBTO's stations have two sets of three hydrophones separated by several kilometres, which - like a pair of human ears - allow listeners to get a fix on a sound's direction to within $0.5^{\circ}$.

Duncan and his colleagues now plan to recover and analyse data from the two IMOS stations off northwestern Australia. But those loggers record only 5 minutes of sound every 15 minutes, and any signals are likely to be contaminated with noise from seismic surveys, says Duncan. He reckons that there is only a "slight chance" that their data will contain the signal, but that it is "worth a go". The team had planned to recover the sensors in September or 
October, but now hopes to make the 7-9-day round trip in August. "Given the continuing uncertainty regarding the fate of $\mathrm{MH} 370$, underwater acoustic data still has the possibility of adding something to the search," says Mark Prior, a CTBTO seismic-acoustic officer.

Meanwhile, it is unclear what other sources of hydrophone data that could be used in the search exist in the region. The US Navy deployed vast arrays of hydrophones on the ocean floor during the cold war for antisubmarine warfare. Details of the Sound Surveillance System (SOSUS) remain secret, but most of the hydrophones are thought to have been deployed off the US Atlantic and Pacific coasts.

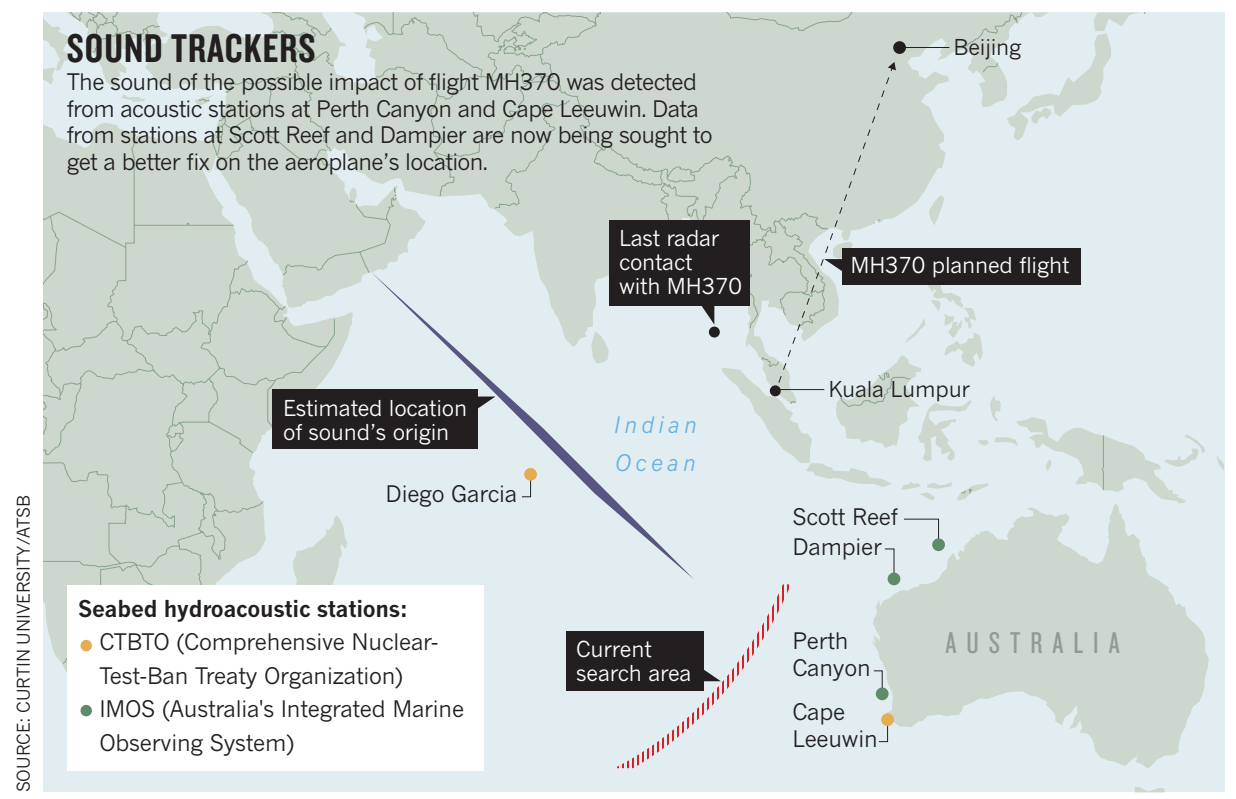

Once the cold war ended, however, the system was downgraded. The data are still being collected, but they are not routinely analysed unless there is an underwater threat. William Marks, a spokesman for the US Navy in Yokosuka, Japan, declined to comment on whether the United States had hydrophones in the region. "Discussions of the SOSUS system at that level are classified," he says. "This is a very sensitive system."

India and Pakistan also have submarine fleets, but Duncan and other scientists say that they do not know whether they or any other nation has hydrophones in the Indian Ocean. "We have not been advised of any hydrophone facilities operated by India or Pakistan," says the JACC spokesperson.

\section{CORRECTIONS}

The News story 'Phage therapy gets revitalized' (Nature 510, 15-16; 2014) mischaracterized the CRISPR mechanism for tackling antibiotic-resistant microbes. It should have said that the phage injects DNA into the bacterium, which then transcribes it into RNA. And in the News story 'Chicken project gets off the ground' (Nature 509, 546; 2014), the mentions of 'guinea fowl' should have read 'jungle fowl'. 